\title{
IL17RB Gene
}

National Cancer Institute

\section{Source}

National Cancer Institute. IL17RB Gene. NCI Thesaurus. Code C97967.

This gene plays a role in both cytokine binding and signaling. 